\title{
Peningkatan Iklim Kelas dan Sikap Ilmiah Siswa Berbasis Model Guided Inquiry Learning di SMA
}

\section{Increasing Classroom Climate and Student Scientific Attitude Using Guided Inquiry Learning Model at High School}

\author{
Mutiara Arum Sari ${ }^{1, *}$, Joko Ariyanto $^{1}$, Maridi ${ }^{1}$ \\ ${ }^{1}$ Pendidikan Biologi FKIP UNS, Jalan Ir.Sutami 36A Kentingan, Surakarta, Indonesia \\ *Corresponding authors: mutiaraarumsari@student.uns.ac.id \\ Manuscript received: ......... Revision accepted:
}

\begin{abstract}
The research aimed to increase classroom climate and student scientific attitude at class XI student of Science Senior High School by implementing guided inquiry learning model. This research was a Classroom Action Research that performed within 3 cycles. Each cycle consisted of 4 steps, there are planning, action, observing, and reflecting. The research subject is 43 students of class XI student of Science Senior High School. The research data were obtained by observation, questionnaire, interview, and documentation. Data was validated using a triangulation method. Data was analyzed using a analysis descriptive technique. The research prosedure was used the spiral model by Kemmis and Mc. Taggart. The research result shows that classroom climate and scientific attitude were increased. Classroom climate on cycle I is 70,24\%, on cycle II is $73,25 \%$, on cycle III is $77,43 \%$. Scientific attitude on cycle I is $72,35 \%$, on cycle II is $74,98 \%$, on cycle III is $79,87 \%$. Guided Inquiry Learning model is able to increase classroom climate and scientific attitude.
\end{abstract}

Keywords: Classroom Climate, Scientific Attitude, Guided Inquiry Learning

\section{PENDAHULUAN}

Indonesia menghadapi tantangan per-saingan bangsa di era global yang menuntut peningkatan kualitas dan produktivitas manusia terdidik (Suryadi, 2014). Perwujudan ke-mandirian dalam upaya meningkatkan kualitas dan produktivitas manusia terdidik dapat diwujudkan melalui pendidikan yang bermutu, relevan, dan berkeadilan. Suryadi (2014) juga menyatakan bahwa pendidikan nasional sampai saat ini masih mengalami kesulitan dalam menghasilkan lulusan yang berkualitas, cakap, dan kreatif yang dapat berfungsi sebagai sumber penggerak dalam berbagai bidang pem-bangunan. Pendidikan Indonesia umumnya memfokuskan orientasinya yang sangat lemah terhadap tumbuhnya nilainilai hakiki ke-manusiaan. Sumber-sumber masalah lainnya juga muncul dari birokrasi dalam pengelolaan pendidikan, pengembangan kurikulum sekolah, proses pembelajaran, evaluasi belajar, hingga ukuran keberhasilannya.

Salah satu upaya yang dapat dilakukan guru untuk menyelesaikan permasalahan yang bersumber dari proses pembelajaran dapat diwujudkan dengan menciptakan iklim kelas yang kondusif dan mengembangkan sikap ilmiah siswa. Iklim kelas yang kondusif berperan penting dalam menunjang ke-terlaksanaan proses pembelajaran di kelas. Menurut Hadiyanto \& Subiyanto (2003), iklim kelas yang kondusif antara lain dapat mendukung: (1) interaksi yang bermanfaat di antara peserta didik, (2) memperjelas pengalaman-pengalaman guru dan peserta didik, (3) menumbuhkan semangat yang memungkin-kan kegiatankegiatan di kelas berlangsung dengan baik, dan (4) mendukung saling pengertian antara guru dan peserta didik (Widoyoko, 2012).

Iklim kelas adalah segala situasi yang muncul akibat hubungan antara guru dan siswa atau hubungan antarsiswa yang menjadi ciri khusus dari kelas dan mempengaruhi proses pembelajaran (Widoyoko, 2012). Otami, Ampiah, \& Anthony-Krueger (2012) me-nyatakan bahwa iklim kelas terdiri dari empat aspek meliputi kesamaan perlakuan guru (equity), kerjasama siswa (cooperation), kekompakan siswa (student cohesivenees), dan dukungan guru (teacher support). Guru memiliki peranan penting dalam menciptakan suasana (iklim) belajar yang menarik bagi siswa (Dimyati \& Mudjiono, 2010). Guru sebagai fasilitator berperan dalam menciptakan interaksi antara guru dengan siswa maupun siswa dengan siswa. Interaksi yang terjadi dalam proses pembelajaran Biologi dapat mendorong siswa untuk berpartisipasi secara aktif dalam proses belajar mengajar sehingga proses pembelajaran berjalan dengan lancar.

Sikap ilmiah juga berperan penting dalam menunjang keterlaksanaan proses pembelajaran di kelas. Johnson \& Johnson (2002) menyatakan bahwa sikap berperan penting dalam me-nentukan perilaku. Pembelajaran yang dapat menciptakan minat dan antusiasme, membuat proses pembelajaran menjadi lebih mudah, lebih cepat, dan hasil belajar menjadi lebih tinggi. Sikap ilmiah siswa yang muncul dan berkembang selama proses pembelajaran dapat membantu siswa dalam memecahkan berbagai permasalahan khususnya masalah-masalah dalam Biologi. Sikap ilmiah siswa tidak hanya bermanfaat selama proses 
pembelajaran di kelas saja, melainkan dapat dimanfaatkan dalam kehidupan sehari-hari.

Sikap ilmiah merupakan reaksi positif atau negatif terhadap kelas yang muncul akibat stimulus dan sesuai dengan etika sains (Olasehinde \& Olatoye, 2014). Menurut Depdiknas (2003), sikap ilmiah terdiri dari beberapa aspek meliputi (1) mengembangkan keingintahuan, (2) berani dan santun dalam mengajukan pertanyaan dan berargumentasi, (3) berani mengusulkan perbaikan atas suatu kondisi dan bertanggung jawab terhadap usulan-nya, (4) bekerjasama, (5) jujur terhadap fakta, serta (6) tekun dan tidak mudah menyerah. Sikap ilmiah sebenarnya sudah dimiliki oleh masing-masing individu. Sikap ilmiah yang sudah dimiliki siswa perlu dilatih dan dikembangkan dengan bantuan guru. Guru berperan penting dalam menciptakan aktivitas yang dapat merangsang siswa mengembangkan sikap ilmiah disetiap proses pembelajaran Biologi. Sikap ilmiah dapat dikembangkan melalui kegiatan-kegiatan yang mengikutserta-kan siswa untuk bekerja secara ilmiah seperti kegiatan kerjasama tim maupun kegiatan praktikum.

Hasil observasi awal terhadap pembelajaran Biologi di kelas XI IPA SMA melalui pengamatan langsung pada hari Rabu, 27 Januari 2016, proses pembelajaran Biologi di kelas bersifat pasif. Guru mendominasi siswa di dalam proses pembelajaran. Guru menggunakan metode ceramah dalam menyampaikan materi Biologi. Guru bahkan tidak mengadakan kerjasama tim ataupun praktikum dalam proses pembelajaran Biologi. Proses pembelajaran belum terfokus kepada siswa. Siswa lebih banyak diam dan memilih mendengarkan penjelasan dari guru. Siswa lebih sering mencatat materi pembelajaran dibandingkan berdiskusi. Siswa sesekali bertanya kepada guru hanya untuk mengulang materi yang belum jelas. Beberapa siswa juga nampak tidak memperhatikan guru, berbincang dengan teman lainnya, menggambar, memainkan handphone bahkan tiduran di kelas. Kegiatan proses pembelajaran Biologi di kelas menunjukkan bahwa iklim kelas dan sikap ilmiah siswa yang rendah.

Salah satu penyebab yang menjadi faktor utama rendahnya iklim kelas dan sikap ilmiah siswa adalah metode pembelajaran guru. Metode pembelajaran yang digunakan guru dalam pembelajaran Biologi adalah metode konvensional atau metode ceramah. Guru menyampaikan materi pembelajaran Biologi dengan memberi ceramah selama proses pembelajaran Biologi. Metode ceramah hanya menciptakan interaksi satu arah yaitu interaksi guru dengan siswa. Metode ceramah tidak memberikan kesempatan kepada siswa untuk berinteraksi satu sama lain sehingga siswa kurang berpartisipasi aktif dalam pembelajaran. Siswa cenderung tidak memperhatikan guru. Siswa terlihat lebih banyak melakukan kegiatan-kegiatan lainnya selama proses pembelajaran Biologi, diantaranya berbincang dengan teman lainnya, menggambar, memainkan hp bahkan tiduran di kelas. Faktor lain yang menjadi penyebab rendahnya iklim kelas dan sikap ilmiah siswa disebabkan karena guru tidak memfasilitasi siswa melakukan kerjasama tim. Tidak adanya kerjasama tim menyebabkan siswa tidak dapat bekerja secara ilmiah sehingga sikap ilmiah siswa tidak dapat berkembang.

Hasil observasi lanjutan terhadap pembelajaran Biologi di kelas XI IPA SMA melalui pengamatan langsung pada hari Kamis, 3 Maret 2016 menunjukkan bahwa iklim kelas dan sikap ilmiah siswa masih rendah. Rata-rata hasil observasi lanjutan iklim kelas sebesar 28,57\% dan sikap ilmiah siswa sebesar $26,19 \%$. Rendahnya iklim kelas pada pembelajaran Biologi ditunjukkan melalui beberapa aspek meliputi kesamaan perlakuan guru sebesar 22,86\%, kerjasama siswa sebesar 40\%, kekompakan siswa sebesar $22,86 \%$, dan dukungan guru sebesar $28,57 \%$. Rendahnya sikap ilmiah siswa pada pembelajaran Biologi juga ditunjukkan melalui beberapa aspek meliputi rasa ingin tahu sebesar $54,29 \%$, berani dan santun dalam mengajukan pertanyaan dan berargumentasi sebesar $20 \%$, berani mengusulkan perbaikan atas suatu kondisi dan bertanggung jawab terhadap usulannya sebesar $0 \%$, bekerjasama sebesar $40 \%$, jujur sebesar $0 \%$, serta tekun dan tidak mudah menyerah sebesar $42,86 \%$.

Hasil observasi lanjutan terhadap pem-belajaran Biologi di kelas XI IPA SMA pada hari Kamis, 3 Maret 2016 juga diperkuat melalui keterangan guru bahwa iklim kelas dan sikap ilmiah siswa pada pembelajaran Biologi dianggap masih kurang. Guru menyatakan bahwa kerjasama siswa dan kekompakan siswa cukup berkembang hanya saat siswa melakukan praktikum atau kerja kelompok. Saat tidak ada kegiatan praktikum atau kerja kelompok, kerjasama dan kekompakan siswa tidak begitu terlihat. Kesamaan perlakuan guru terhadap siswa diakui guru dilakukan secara berbeda. Guru menyatakan bahwa perbedaan perlakuan guru karena menyesuaikan karakter siswa dan kebutuhan siswa. Dukungan guru kepada siswa diakui selalu diberikan guru selama proses pembelajaran Biologi berlangsung. Guru juga menyatakan bahwa sikap ilmiah siswa dalam pembelajaran Biologi belum begitu nampak. Pernyataan guru didukung oleh pernyataan siswa bahwa iklim kelas dan sikap ilmiah siswa di kelas XI IPA SMA masih kurang.

Hasil observasi di kelas XI IPA SMA menunjukkan bahwa iklim kelas dan sikap ilmiah siswa pada pembelajaran Biologi tergolong rendah. Rendahnya iklim kelas dan sikap ilmiah siswa teridentifikasi disebabkan karena model pembelajaran yang digunakan guru belum mampu mendorong siswa untuk berpartisipasi aktif dalam proses pembelajaran Biologi. Guru perlu memiliki kemampuan khusus untuk memilih dan mengimplementasi-kan model yang tepat untuk diterapkan dalam mengatasi berbagai permasalahan pada pembelajaran Biologi di kelas. Model pem-belajaran yang dapat menjadi solusi untuk mengatasi masalah rendahnya iklim kelas dan sikap ilmiah siswa pada pembelajaran Biologi di kelas XI IPA SMA adalah model pembelajaran Guided Inquiry.

Inquiry (inkuiri) merupakan model pem-belajaran yang melibatkan siswa secara aktif untuk mencari dan menemukan konsep-konsep ataupun fakta-fakta yang ada di lingkungannya melalui eksperimen yang dilakukannya sendiri. Pada model pembelajaran Guided Inquiry, guru 
masih memberikan bimbingan di tahap awal pembelajaran. Bimbingan guru akan semakin berkurang pada tahap pembelajaran berikutnya terutama pada tahap siswa menentukan prosedur penelitian dan solusi/ jawaban. Model pem-belajaran Guided Inquiry menempatkan siswa sebagai subjek pembelajaran dan guru sebagai pembimbing sekaligus fasilitator pembelajaran. Hubungan antara iklim kelas dan model pembelajaran Guided Inquiry yaitu model pembelajaran Guided Inquiry menitikberatkan adanya interaksi yang terjadi antara guru dengan siswa maupun siswa dengan siswa. Hubungan antara sikap ilmiah dan model pembelajaran Guided Inquiry yaitu model pembelajaran Guided Inquiry menekankan siswa untuk bekerja secara ilmiah disetiap tahapan pembelajaran.

Berdasarkan uraian latar belakang diatas, perlu dilakukan penelitian dengan judul: "Peningkatan Iklim Kelas dan Sikap Ilmiah Siswa berbasis Model Guided Inquiry Learning di kelas XI IPA 2 SMA Muhammadiyah 1 Karanganyar Tahun Ajaran 2015/ 2016".

Berdasarkan latar belakang masalah, dirumuskan permasalahan, yaitu: Apakah model Guided Inquiry Learning dapat meningkatkan iklim kelas dan sikap ilmiah siswa di kelas XI IPA SMA?

Tujuan penelitian adalah untuk meningkat-kan iklim kelas dan sikap ilmiah siswa melalui penerapan model Guided Inquiry Learning di kelas XI IPA SMA.

Hasil penelitian diharapkan dapat memberikan gambaran secara jelas kepada guru mengenai model Guided Inquiry Learning sehingga mampu diaplikasikan dengan optimal dalam meningkatkan iklim kelas dan sikap ilmiah siswa.

\section{METODE PENELITIAN}

Penelitian dilaksanakan di SMA yang memiliki total keseluruhan siswa berjumlah 1168 pada tahun ajaran 2015/ 2016 yang terdiri dari 579 siswa kelas X yang dibagi menjadi 14 rombongan belajar, 367 siswa kelas XI yang dibagi menjadi 13 rombongan belajar, dan 222 siswa kelas XII yang dibagi menjadi 6 rombongan belajar. Penelitian dilaksanakan pada bulan April-Mei semester genap tahun ajaran 2015/ 2016. Penelitian dilaksanakan dalam tiga tahapan, yaitu tahap persiapan, tahap pelaksanaan, dan tahap penyelesaian.

Penelitian yang digunakan adalah Penelitian Tindakan Kelas (PTK) atau Classroom Action Reasearch (CAR). Penelitian Tindakan Kelas adalah penelitian tindakan (action research) yang dilaksanakan oleh guru di dalam kelas. Penelitian tindakan dilakukan atas dasar berbagai permasalahan yang muncul di dalam kelas. Tindakan diberikan oleh guru atau dengan arahan dari guru yang dilakukan oleh siswa. Penelitian Tindakan Kelas bertujuan untuk mengatasi permasalahan yang ada di kelas. Menurut Kusumah \& Dwitagama (2012), PTK terdiri dari langkahlangkah operasional penelitian, yaitu tahap perencanaan (planning), tindakan (acting), pengamatan (observing), dan refleksi (reflecting). Keempat langkah operasional penelitian akan terus berulang di setiap siklus dari siklus pertama ke siklus selanjutnya. Penelitian di kelas XI IPA SMA pada pokok bahasan sistem indera dengan penerapan model Guided inquiry Learning dilakukan sebanyak tiga siklus yang diawali dengan kegiatan pra siklus.

Data penelitian yang dikumpulkan berupa data mengenai iklim kelas dan sikap ilmiah siswa dalam pembelajaran biologi di kelas. Data penelitian diperoleh dari beberapa sumber, yaitu hasil observasi observer selama proses pembelajaran, data hasil pengisian angket iklim kelas dan sikap ilmiah siswa, hasil wawancara guru maupun siswa sebelum dan sesudah penerapan model Guided Inquiry Learning, serta lembar observasi keterlaksanaan sintaks model Guided Inquiry Learning guru maupun siswa. Data pendukung penelitian juga diperoleh dari beberapa sumber, yaitu silabus, Rancangan Pelaksanaan Pembelajaran (RPP), Lembar Kerja Siswa (LKS), dan dokumentasi kegiatan selama proses pembelajaran.

Teknik pengumpulan data yang digunakan dalam penelitian, yaitu teknik non-test. Teknik non-test pada penelitian iklim kelas dan sikap ilmiah siswa pada pembelajaran biologi meliputi angket, observasi, dan wawancara. Teknik yang digunakan untuk menguji validitas data dalam penelitian yang telah dikumpulkan yaitu teknik triangulasi. Metode pengumpulan data yang digunakan dalam penelitian meliputi observasi, angket, wawancara, dan dokumentasi. Teknik yang digunakan untuk menganalisis data dalam penelitian yang telah dikumpulkan yaitu teknik analisis deskriptif kualitatif. Teknik analisis data mengacu pada model analisis Miles dan Huberman. Prosedur penelitian yang digunakan dalam penelitian mengacu pada model yang dikembangkan oleh Kemmis dan Mc. Taggart berupa model spiral (Kusumah \& Dwitagama, 2012). Target prosentase capaian penelitian iklim kelas dan sikap ilmiah siswa disimpulkan sebesar 75\% di setiap aspek pada akhir siklus penelitian.

\section{HASIL PENELITIAN DAN PEMBAHASAN}

Iklim kelas dan sikap ilmiah siswa kelas XI IPA SMA mengalami peningkatan skor capaian. Penerapan model pembelajaran Guided Inquiry pada tahap tindakan siklus I, siklus II dan siklus III mampu meningkatkan skor capaian iklim kelas dan sikap ilmiah siswa disetiap siklusnya hingga mencapai skor target yang telah ditentukan. Peningkatan skor capaian iklim kelas dan sikap ilmiah siswa sebagai berikut:

\section{Iklim Kelas}




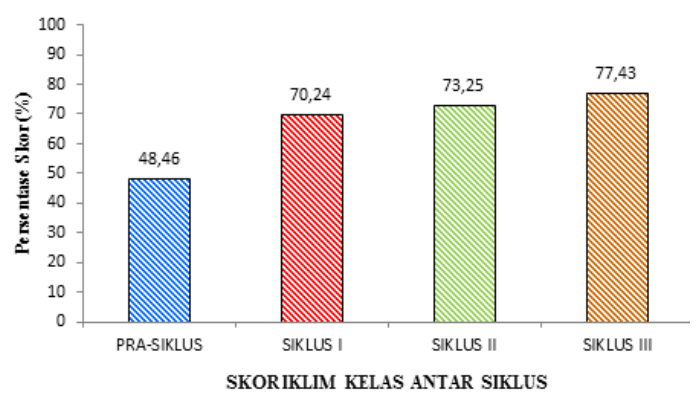

Gambar 1. Peningkatan Persentase Skor Capaian Iklim Kelas Pra-Siklus, Siklus I, Siklus II dan Siklus III

Berdasarkan gambar 1 hasil analisis peningkatan persentase skor capaian iklim kelas di kelas XI IPA SMA mengalami peningkatan disetiap siklusnya. Persentase skor capaian iklim kelas disetiap siklusnya dari tahap pra-siklus sebesar $48,46 \%$ menjadi $70,24 \%$ pada tahap siklus I, dari siklus I menjadi 73,25\% pada tahap siklus II, dari siklus II menjadi $77,43 \%$ pada tahap siklus III. Persentase rata-rata peningkatan skor capaian iklim kelas dari tahap pra-siklus ke siklus I sebesar $21,78 \%$, dari tahap siklus I ke siklus II sebesar 3,01\%, dari tahap siklus II ke siklus III sebesar $4,18 \%$. Skor capaian iklim kelas pada akhir siklus sudah melampaui target capaian sebesar $75 \%$. Peningkatan skor capaian aspek iklim kelas.

Tabel 1. Peningkatan Persentase Skor Capaian Aspek Iklim Kelas Pra-Siklus, Siklus I, Siklus II dan Siklus III

\begin{tabular}{ccccc}
\hline \multirow{2}{*}{ Aspek } & \multicolumn{4}{c}{ Skor Capaian (\%) } \\
\cline { 2 - 5 } & Pra-Siklus & Siklus I & Siklus II & Siklus III \\
\hline $\begin{array}{c}\text { Kesamaan Perlakuan } \\
\text { Guru (Equity) } \\
\text { Kerjasama Siswa } \\
\text { (Cooperation) }\end{array}$ & 46,48 & 69,65 & 72,79 & 75,84 \\
$\begin{array}{c}\text { Kekompakan Siswa } \\
\text { (Cohesiveness) }\end{array}$ & 42,61 & 66,65 & 70,19 & 74,94 \\
$\begin{array}{c}\text { Dukungan Guru } \\
\text { (Teacher Support) }\end{array}$ & 50,99 & 72,42 & 76,15 & 82,6 \\
\hline Jumlah & 193,82 & 280,94 & 292,99 & 309,7 \\
\hline Rata-rata & 48,46 & 70,24 & 73,25 & 77,43 \\
\hline
\end{tabular}

Berdasarkan tabel 1 persentase skor capaian pada masing-masing aspek iklim kelas di kelas XI IPA SMA mengalami peningkatan skor capaian di setiap siklus dari tahap pra-siklus, siklus I, siklus II dan siklus III. Aspek kesamaan perlakuan guru (equity) pada tahap pra-siklus sebesar $46,48 \%$ meningkat menjadi $69,65 \%$ pada siklus I, siklus I meningkat menjadi $72,79 \%$ pada siklus II, dan siklus II meningkat menjadi 75,84\% pada siklus III. Aspek kerjasama siswa (cooperation) pada tahap pra-siklus sebesar $53,74 \%$ meningkat menjadi $72,22 \%$ pada siklus I, siklus I meningkat menjadi $73,86 \%$ pada siklus II, dan siklus II meningkat menjadi 76,32\% pada siklus III. Aspek kekompakan siswa (cohesiveness) pada tahap pra-siklus sebesar $42,61 \%$ meningkat menjadi $66,65 \%$ pada siklus I, siklus I meningkat menjadi 70,19\%, siklus II meningkat menjadi $74,94 \%$ pada siklus III. Aspek dukungan guru (teacher support) pada tahap pra-siklus sebesar 50,99\% meningkat menjadi $72,42 \%$ pada siklus I, siklus I meningkat menjadi 76,15 pada siklus II, siklus II meningkat menjadi $82,60 \%$ pada siklus III.

Peningkatan iklim kelas di kelas XI IPA SMA didukung oleh hasil kegiatan wawancara yang dilakukan kepada guru dan siswa. Hasil wawancara menunjukkan bahwa peningkatan ditandai dengan guru memberikan perlakuan yang sama kepada siswa, siswa saling bekerjasama, siswa kompak satu sama lain, dan guru memberikan dukungan kepada siswa. Peningkatan tersebut menunjukkan bahwa iklim kelas di kelas XI IPA mengalami peningkatan.

\section{Sikap Ilmiah}

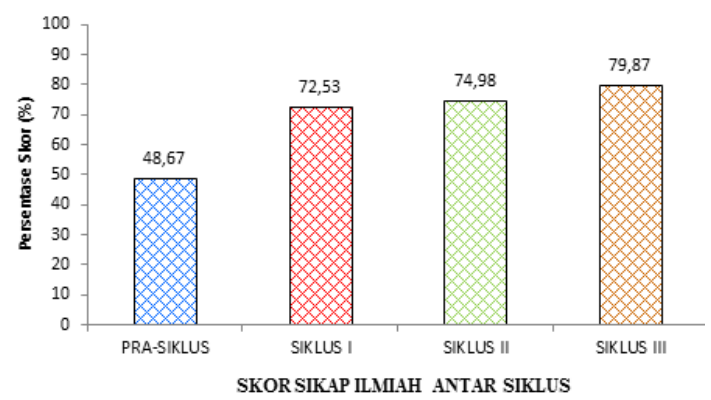

Gambar 2. Peningkatan Persentase Skor Capaian Sikap Ilmiah Siswa Pra-Siklus, Siklus I, Siklus II dan Siklus III

Berdasarkan gambar 2 menunjukkan bahwa skor capaian sikap ilmiah siswa di kelas XI IPA SMA mengalami peningkatan pada tahap pra-siklus, siklus I, siklus II dan siklus III. Skor capaian sikap ilmiah siswa dari tahap prasiklus sebesar $48,67 \%$ menjadi $72,53 \%$ pada siklus I, dari siklus I menjadi $74,98 \%$ pada siklus II, dari siklus II menjadi $79,87 \%$ pada siklus III. Skor capaian sikap ilmiah siswa mengalami peningkatan sebesar $23,87 \%$ dari prasiklus ke siklus I, sebesar 2,44\% dari siklus I ke siklus II dan sebesar $4,9 \%$ dari siklus II ke siklus III. \%. Skor capaian sikap ilmiah siswa pada akhir siklus sudah melampaui target capaian sebesar $75 \%$. Peningkatan skor capaian aspek sikap ilmiah siswa. 
Tabel 2. Peningkatan Persentase Skor Capaian Aspek Sikap Ilmiah Siswa Pra-Siklus, Siklus I, Siklus II dan Siklus III

\begin{tabular}{ccccc}
\hline \multirow{2}{*}{ Aspek } & \multicolumn{4}{c}{ Skor Capaian (\%) } \\
\cline { 2 - 5 } & Pra-Siklus & Siklus I & Siklus II & Siklus III \\
\hline A & 63,36 & 75,83 & 79,85 & 84,38 \\
B & 45,66 & 69,08 & 71,25 & 76,25 \\
C & 35,85 & 67,11 & 68,44 & 74,07 \\
D & 56,40 & 75,66 & 76,72 & 79,38 \\
E & 32,91 & 75,17 & 80,32 & 87,66 \\
F & 57,83 & 72,37 & 73,28 & 76,25 \\
\hline Jumlah & 292,01 & 435,22 & 449,86 & 477,99 \\
\hline Rata-rata & 48,67 & 72,54 & 74,98 & 79,67 \\
\hline
\end{tabular}

Keterangan:

A : Rasa ingin tahu

B : Berani dan santun dalam mengajukan pertanyaan dan berargumentasi

C : Berani mengusulkan perbaikan atas suatu kondisi dan bertanggungjawab terhadap usulannya

D : Bekerjasama

E : Jujur

F : Tekun dan tidak mudah menyerah

Berdasarkan tabel 2 skor capaian pada masing-masing aspek sikap ilmiah siswa kelas XI IPA SMA mengalami peningkatan skor capaian dari pra-siklus, siklus I, siklus II dan siklus III. Persentase skor capaian aspek rasa ingin tahu meningkat dari tahap pra-siklus sebesar $63,36 \%$ menjadi $75,83 \%$ pada siklus I, siklus I meningkat menjadi $79,85 \%$ pada siklus II, dan siklus II meningkat menjadi $84,38 \%$ pada siklus III. Persentase skor capaian aspek berani dan santun dalam mengajukan pertanyaan dan berargumentasi meningkat dari tahap pra-siklus sebesar $45,66 \%$ menjadi $69,08 \%$ pada siklus I, siklus I meningkat menjadi $71,25 \%$ pada siklus II, dan siklus II meningkat menjadi 76,25\% pada siklus III. Persentase skor capaian aspek berani mengusulkan perbaikan atas kondisi dan bertanggungjawab terhadap usulannya meningkat dari tahap pra-siklus sebesar $35,85 \%$ menjadi $67,11 \%$ pada siklus I, siklus I meningkat menjadi $68,44 \%$ pada siklus II, siklus II meningkat menjadi $74,07 \%$ pada siklus III. Persentase skor capaian aspek bekerjasama meningkat dari tahap pra-siklus sebesar $56,40 \%$ menjadi $75,66 \%$ pada siklus I, siklus I meningkat menjadi $76,72 \%$ pada siklus II, dan siklus II meningkat menjadi $79,38 \%$ pada siklus III. Skor capaian aspek jujur meningkat dari tahap pra-siklus sebesar $32,91 \%$ menjadi $75,17 \%$ pada tahap siklus I, siklus I meningkat menjadi $80,32 \%$ pada tahap siklus II, dan siklus II meningkat menjadi $87,66 \%$ pada tahap siklus III. Skor capaian aspek tekun dan tidak mudah menyerah meningkat dari tahap pra-siklus sebesar 57,83\% menjadi $72,37 \%$ pada siklus I, siklus I meningkat menjadi $73,28 \%$ pada siklus II, dan siklus II meningkat menjadi $76,25 \%$ pada siklus III.

Peningkatan sikap ilmiah siswa didukung dengan hasil kegiatan wawancara dengan guru dan siswa. Hasil wawancara guru dan siswa menunjukkan bahwa peningkatan sikap ilmiah siswa ditandai dengan kemajuan pada rasa ingin tahu terhadap media pembelajaran, sikap berani bertanya dan berargumentasi, sikap berani memberikan usulan kepada anggota kelompok, saling bekerjasama, jujur dalam menyampaikan data hasil penelitian, serta sikap tekun dan tidak mudah menyerah. Peningkatan tersebut menunjukkan bahwa sikap ilmiah siswa di kelas XI IPA mengalami peningkatan.

Iklim kelas adalah segala situasi yang muncul akibat hubungan antara guru dan siswa atau hubungan antarsiswa yang menjadi ciri khusus dari kelas dan mempengaruhi proses pembelajaran (Widoyoko, 2012). Konsep iklim kelas yang diterapkan dalam pengaturan pendidikan dipandang sebagai tempat bagi peserta didik dengan guru berinteraksi satu sama lain dan menggunakan berbagai alat dan sumber daya informasi dalam mengejar kegiatan pembelajaran mereka (Fout \& Mayer 1998, Mucherah 2008 dalam Otami, Ampiah, Anthony-Krueger 2012). Otami, Ampiah, Anthony-Krueger (2012) juga menambahkan bahwa menciptakan iklim kelas yang kondusif hendaknya menjadi suatu hal yang penting terutama bagi guru sains karena berdasarkan hasil penelitian membuktikan bahwa iklim kelas dapat mempengaruhi pembelajaran siswa. Iklim kelas diukur melalui kegiatan observasi selama pembelajaran biologi berlangsung dengan menggunakan instrumen berupa lembar observasi dan angket yang didukung dengan dokumentasi.

Hasil analisis instrumen lembar observasi dan angket iklim kelas menunjukkkan bahwa iklim kelas siswa di kelas XI IPA SMA mengalami peningkatan persentase skor disetiap siklusnya. Peningkatan persentase skor iklim kelas terjadi karena model pembelajaran Guided Inquiry diterapkan pada tahap tindakan siklus I, siklus II dan siklus III. Pada tahap tindakan siklus I, model pembelajaran Guided Inquiry diterapkan pada materi bab Sistem Indera dengan topik pembelajaran Sistem Indera pada Manusia. Guru memfasilitasi siswa untuk melakukan kegiatan praktikum tentang struktur, fungsi dan proses sistem indera pada manusia meliputi indera penciuman, indera perasa, indera pengelihatan, indera pendengaran, dan indera peraba. Guru dan siswa mencoba beradaptasi dengan model pembelajaran Guided Inquiry karena belum terbiasa. Interaksi terjadi antara siswa dengan siswa selama kegiatan diskusi berlangsung. Interaksi juga terjadi antara siswa dengan guru ketika siswa mengalami kesulitan dalam melaksanakan kegiatan penyelidik-n. Pada tahap tindakan siklus I, interaksi siswa dengan siswa maupun siswa dengan guru mengalami peningkatan dari tahap pra-siklus. Persentase skor capaian iklim kelas pada tahap siklus I sebesar 70,24\% meningkat dari tahap pra-siklus meskipun belum memenuhi skor capaian target sebesar $75 \%$.

Pada tahap tindakan siklus II, model pembelajaran Guided Inquiry diterapkan pada materi bab Sistem Indera dengan topik pembelajaran Kelainan dan Penyakit pada Sistem Indera Manusia. Guru memfasilitasi siswa melakukan kegiatan praktikum melalui kajian literatur tentang kelainan/ penyakit pada sistem indera manusia. Guru dan siswa mulai terbiasa dengan penerapan model pembelajaran Guided Inquiry untuk kedua kalinya. Interaksi siswa dengan siswa maupun siswa dengan guru 
semakin intensif terjadi. Kegiatan kajian literatur menuntut siswa untuk aktif membaca dalam upaya memahami isi artikel tentang kelainan/ penyakit pada sistem indera manusia. Istilah-istilah yang ada didalam artikel kelainan/ penyakit pada sistem indera manusia yang tidak biasa terdengar menuntut siswa untuk bertanya kepada sesama siswa maupun kepada guru. Persentase skor capaian iklim kelas pada tahap siklus II sebesar 73,25\% meningkat dari tahap siklus I. Persentase skor capaian iklim kelas pada tahap siklus I masih belum memenuhi skor capaian target sebesar 75\% sehingga harus dilanjutkan ke tahap siklus III.

Pada tahap tindakan siklus III, model pembelajaran Guided Inquiry diterapkan pada materi bab Sistem Indera dengan topik pembelajaran Sistem Indera pada Hewan Vertebrata dan Invertebrata. Pada tahap siklus III, guru dan siswa sudah terbiasa dengan penerapan model pembelajaran Guided Inquiry. Guru memfasilitasi siswa melaksanakan kegiatan penyelidikan yang dihadapkan dengan hewan vertebrata dan invertebrata yang sesungguhnya. Rasa penasaran siswa terhadap masingmasing hewan vertebrata maupun invertebrata membuat siswa bertanya-tanya. Siswa banyak bertanya kepada siswa lainnya dan sesekali bertanya kepada guru. Interaksi siswa dengan siswa maupun siswa dengan guru semakin intensif terjadi selama kegiatan pembelajaran biologi berlangsung. Persentase skor capaian iklim kelas pada tahap siklus III sebesar $77,42 \%$ sudah melampaui skor capaian target sebesar $75 \%$.

Penerapan model pembelajaran Guided Inquiry mengajak siswa aktif berpartisipasi disetiap kegiatan dalam pembelajaran biologi. Menurut Gulo (2002), inkuiri berarti suatu rangkaian kegiatan belajar yang melibatkan secara maksimal seluruh kemampuan siswa untuk mencari dan menyelidiki secara sistematis, kritis, logis, dan analitis, sehingga dapat merumuskan sendiri penemuannya dengan penuh percaya diri. Materi bab Sistem Indera yang terkait dengan kehidupan sehari-hari menambah antusias siswa untuk mencari tahu lebih dalam lagi mengenai materi yang sedang dipelajari, yaitu sistem indera pada manusia maupun sistem indera pada hewan. Pengetahuan awal yang sudah dimiliki siswa terkait materi bab Sistem Indera menjadi bekal utama siswa dalam melakukan kegiatan penyelidikannya sendiri.

Siswa menunjukkan adanya peningkatan interaksi yang terjadi antara siswa dengan siswa maupun siswa dengan guru. Permasalahan yang dihadapi siswa pada kegiatan penyelidikan mengharuskan siswa saling bertukar informasi dan pendapat untuk menyelesaikan masalah. Siswa secara intensif berinteraksi dengan sesama siswa ketika siswa berdiskusi dalam me-laksanakan kegiatan penyelidikan bersama dengan siswa lainnya. Siswa hanya sesekali berinteraksi dengan guru ketika siswa membutuhkan penjelasan atau mengalami kesulitan selama kegiatan penyelidikan. Interaksi yang terjadi antara siswa dengan siswa maupun siswa dengan guru sejalan dengan definisi iklim kelas dan prinsip interaksi pada model pembelajaran inkuiri. Pembelajaran inkuiri terdiri dari beberapa prinsip yang harus diperhatikan meliputi (1) berorientasi pada perkembangan intelektual, (2) prinsip interaksi, (3) prinsip bertanya, dan (4) prinsip belajar untuk berpikir (Hamruni, 2012). Prinsip interaksi, yaitu pembelajaran inkuiri terjadi proses interaksi, baik interaksi antar siswa maupun interaksi siswa dengan guru bahkan interaksi siswa dengan lingkungan.

Model pembelajaran Guided Inquiry meningkatkan peran aktif siswa selama proses kegiatan pembelajaran biologi. Siswa me-rancang penyelidikan dan melaksanakan kegiatan penyelidikannya sendiri untuk me-nyelesaikan permasalahan yang dihadapi. Interaksi antara siswa dengan siswa lebih intensif terjadi dibandingkan interaksi siswa dengan guru. Guru banyak memberi kesempatan kepada siswa untuk mengeksplor kemampuan yang dimilikinya dalam melaksanakan kegiatan penyelidikan. Pembelajaran inkuiri merupakan bentuk dari model pembelajaran yang ber-orientasi pada siswa (student centered learning) (Majid, 2013). Prosedur model pembelajaran inkuiri yaitu melibatkan siswa dalam pe-nyelidikan masalah yang sebenarnya (geuine problem) dengan cara melibatkan dalam penelitian, membantu siswa mengidentifikasi konsep atau metode, dan mendorong siswa me-nemukan cara untuk memecahkan masalah yang dihadapi (Joyce, et al, 2000). Model pembelajaran inkuiri dalam proses pembelajaran mendorong terciptanya iklim kelas yang kooperatif yang membutuhkan keterlibatan peserta didik secara aktif (Karwati \& Priansa, 2014).

Model pembelajaran Guided Inquiry mengakomodasi rasa ingin tahu siswa dengan cara melakukan penyelidikan. Guru memberi suatu permasalahan diawal kegiatan pembelajaran untuk memicu rasa ingin tahu siswa. Keingintahuan yang muncul dari siswa mendorongnya untuk bertanya dan mencari tahu dengan caranya sendiri. Siswa diberi kesempatan oleh guru untuk mencari tahu dan menyelesaikan masalah yang dihadapi dengan cara berdiskusi. Guru hanya bertugas memberi bimbingan kepada siswa dan memfasilitasi kegiatan diskusi. Pembelajaran model inkuiri mencoba membawa peserta didik ke dalam situasi yang memberikan kesempatan kepada dirinya untuk menggunakan apa yang telah diketahui dan menyadari apa yang mereka lakukan itu adalah perolehan mereka sendiri, bukan perolehan guru (Alma, 2010). Dalam upaya menanamkan konsep biologi, pem-belajaran akan lebih bermakna jika siswa diberi kesempatan untuk tahu dan terlibat secara aktif dalam menemukan konsep dari fakta-fakta yang dilihat dari lingkungan dengan bimbingan guru (Trianto, 2007). Peran siswa dan guru pada pembelajaran inkuiri relevan dengan hasil penelitian yang dilakukan oleh Tsai \& Tuan (2006) mengenai investigasi dampak Inquiry-Based Instruction terhadap persepsi iklim kelas siswa. Dukungan dan bimbingan guru pada pembelajaran berbasis inkuiri merupakan salah satu bentuk penguatan. Menurut teori belajar Skinner, guru perlu memperhatikan dua hal yang penting, yaitu (1) pemilihan stimulus diskriminatif, dan (ii) penggunaan penguatan (Dimyati \& Mudjiono, 2010). Guru dituntut memberikan penguatan kepada siswa dalam bentuk dukungan maupun bimbingan di setiap tahapan pembelajaran sehingga siswa semakin bersemangat untuk melaksanakan kegiatan penyelidikan. 
Tahapan model pembelajaran Inquiry berbasis ilmu biologi meliputi (1) siswa disaji-kan suatu bidang penelitian (area investigation is posed to student). (2) siswa menyusun masalah (student structure the problem), (3) siswa mengidentifikasi masalah dalam penelitian (student identify the problem in the investigation), dan (4) siswa berspekulasi untuk memperjelas masalah (student speculate on ways to clear up the difficulty). Pada fase 1 dan 2 sintaks model pembelajaran Inquiry, siswa masih mendapatkan bimbingan dari guru sehingga ada interaksi yang terjadi antara guru dan siswa. Pada fase 3 dan 4 sintaks model pembelajaran Inquiry, siswa tidak mendapatkan bimbingan dari guru sehingga siswa harus berusaha sendiri menyelesaikan permasalahan yang dihadapi dengan cara berinteraksi antara siswa satu dengan siswa lainnya. Model pembelajaran Guided Inquiry memfasilitasi siswa untuk melakukan banyak interaksi antara siswa dengan siswa maupun siswa dengan guru. Aspek kesamaan perlakuan guru (equity) dan aspek dukungan guru (teacher support) meningkat pada tahapan model Guided Inquiry Learning fase 1 siswa disajikan suatu bidang penelitian dan fase 2 siswa menyusun masalah. Fase 1 dan 2 pada model pembelajaran Guided Inquiry memfasilitasi guru dan siswa untuk saling berinteraksi melalui beberapa kegiatan seperti guru menyajikan masalah kepada siswa, siswa membuat pertanyaan kepada guru, guru membimbing siswa memfokuskan sub topik pembelajaran, siswa membuat rumusan masalah, tujuan pembelajaran dan hipotesis dengan bimbingan guru. Aspek kerjasama siswa (cooperation) dan aspek kekompakan siswa (cohesiveness) meningkat pada tahapan model Guided Inquiry Learning fase 3 siswa mengidentifikasi masalah dan fase 4 siswa menentukan langkah-langkah untuk menyelesai-kan masalah. Fase 3 dan 4 model pembelajaran Guided Inquiry memfasilitasi siswa untuk saling berinteraksi dengan siswa lainnya. Kegiatan pembelajaran pada fase 3 dan 4 meliputi siswa membuat rancangan penyelidikan, melaksana-kan kegiatan penyelidikan, membaca berbagai literatur terkait tema penyelidikan, mendiskusi-kan hasil pengamatan, membuat kesimpulan dan mempresentasikan hasil pengamatan.

Kecenderungan reaksi positif atau negatif terhadap kelas yang diberi stimulus disebut sebagai sikap (attitude). Reaksi yang muncul akibat stimulus dan sesuai dengan etika sains disebut sebagai sikap ilmiah (scientific attitude). Sikap ilmiah adalah kemampuan untuk bereaksi secara konsisten, rasional, dan objektif dengan cara-cara tertentu terhadap permasalahan keadaan (Olasehinde \& Olatoye, 2014). Sikap ilmiah dalam pembelajaran sains sering dikaitkan dengan sikap terhadap sains (Anwar, 2009). Sikap ilmiah merupakan salah satu bentuk kecerdasan yang dimiliki oleh setiap individu. Sikap sangat erat kaitannya dengan nilai, motivasi, dan dorongan (hasrat melakukan sesuatu) (Rubbini \& Liliasari, 2013). Sikap ilmiah dalam pembelajaran dapat mem-pengaruhi hasil belajar (Fakhruddin, 2010). Sikap ilmiah siswa diukur dengan menggunakan instrumen berupa lembar observasi dan angket yang dibantu dengan dokumentasi selama kegiatan observasi.

Hasil analisis lembar observasi dan angket, penerapan model pembelajaran Guided Inquiry pada pembelajaran biologi di kelas XI IPA SMA meningkatkan sikap ilmiah siswa dari tahap pra-siklus, siklus I, siklus II dan siklus III. Pada tahap tindakan siklus I, penerapan model pembelajaran Guided Inquiry pada materi bab Sistem Indera dengan topik pembelajaran Sistem Indera pada Manusia meningkatkan sikap ilmiah siswa dari tahap prasiklus. Kegiatan penyelidikan yang difasilitasi oleh guru membantu siswa dalam mengembangkan sikap ilmiah yang sebelumnya sudah dimiliki oleh masing-masing siswa. Pada kegiatan awal pembelajaran, guru menampilkan sebuah video terkait sistem indera pada manusia untuk merangsang rasa ingin tahu siswa. Rasa ingin tahu siswa semakin besar ketika siswa dihadapkan pada beberapa alat dan bahan praktikum terkait sistem indera manusia dalam melaksanakan kegiatan penyelidikan bersama dengan siswa lainnya. Siswa mulai menunjuk-kan keaktifannya dalam mengajukan pertanyaan dan memberikan usulannya kepada sesama siswa maupun guru. Siswa juga bersedia bekerjasama dalam melaksanakan kegiatan pe-nyelidikan untuk menjawab rasa ingin tahunya. Persentase skor capaian sikap ilmiah belum memenuhi skor capaian target sebesar $75 \%$ meskipun persentase skor sikap ilmiah siswa pada tahap tindakan siklus I sebesar $72,53 \%$ meningkat dari tahap pra-siklus.

Pada tahap tindakan siklus II, penerapan model pembelajaran Guided Inquiry pada materi bab Sistem Indera dengan topik pembelajaran Kelainan/ Penyakit pada Sistem Indera Manusia mampu meningkatkan sikap ilmiah siswa dari tahap siklus I. Guru menampilkan beberapa gambar kelainan/ penyakit pada sistem indera manusia diawal kegiatan pembelajaran untuk merangsang rasa ingin tahu siswa. Rasa ingin tahu siswa semakin meningkat karena masing-masing kelompok diskusi melakukan kajian literatur sebuah artikel tentang kelainan/ penyakit pada sistem indera yang sudah di-sediakan oleh guru. Siswa semakin berani mengajukan pertanyaan dan menyampaikan usulannya kepada siswa lainnya. Siswa semakin berani bertanya kepada guru ketika siswa merasa kesulitan. Siswa saling membagi tugas dalam bekerjasama. Pada kegiatan presentasi, sebagian besar siswa mempresentasikan data berdasarkan hasil penyelidikannya sendiri. Siswa juga bersedia memperhatikan dari kegiatan awal pembelajaran hingga kegiatan akhir pembelajaran. Persentase skor capaian sikap ilmiah siswa pada tahap siklus II masih berada dibawah skor capaian target sebesar $75 \%$ meskipun mengalami peningkatan dari siklus sebelumnya menjadi $74,98 \%$ pada siklus II.

Pada tahap tindakan siklus III, penerapan model pembelajaran Guided Inquiry pada materi bab Sistem Indera dengan topik pembelajaran Sistem Indera pada Hewan Vertebrata dan Invertebrata meningkatkan sikap ilmiah siswa dari tahap siklus II. Guru menampilkan sebuah video mengenai seekor burung dan serangga diawal kegiatan pembelajaran. Siswa me-laksanakan penyelidikan melalui kegiatan praktikum sistem indera pada hewan 
vertebrata maupun invertebrata yang sudah disediakan oleh guru meliputi serangga, ikan, amfibi, reptil dan burung. Siswa mengamati setiap hewan vertebrata maupun invertebrata yang ada dihadapan mereka dengan antusias. Siswa semakin banyak bertanya kepada siswa lainnya maupun guru tentang hewan yang sedang diamatinya. Siswa juga semakin berani dalam memberikan usulannya selama kegiatan diskusi. Kerjasama siswa semakin baik karena setiap siswa dalam kelompok diskusi mendapatkan tugas yang berbeda. Siswa mempresentasikan data hasil penyelidikannya masing-masing tanpa memanipulasi data hasil penyelidikannya. Ke-tekunan dan sikap pantang menyerah siswa juga ditunjukkan selama kegiatan pembelajaran biologi berlangsung. Persentase skor capaian sikap ilmiah siswa sudah melampaui target sebesar $75 \%$ dengan persentase skor capaian sikap ilmiah siklus III sebesar 79,87\% yang meningkat dari siklus sebelumnya.

Penerapan model pembelajaran Guided Inquiry meningkatkan rasa ingin tahu siswa dalam pembelajaran biologi. Guru memancing rasa ingin tahu siswa dengan menampilkan gambar/ video diawal kegiatan pembelajaran dan menghadapkan siswa pada suatu masalah secara langsung melalui kegiatan praktikum. Keberanian siswa dalam mengajukan per-tanyaan dan berargumentasi juga semakin meningkat seiring dengan diterapkannya model pembelajaran Guided Inquiry. Rasa ingin tahu siswa yang besar menuntut siswa bertanya kepada guru maupun siswa lainnya untuk mendapatkan jawaban atas rasa ingin tahunya. Keberanian siswa dalam menyampaikan usulannya juga semakin meningkat seiring dengan fasilitas yang diberikan guru kepada siswa dalam kegiatan diskusi. Senada dengan Piaget dalam Putra (2013) yang mendefinisikan model inkuiri sebagai pembelajaran yang mem-persiapkan situasi bagi siswa untuk melakukan eksperimen sendiri; dalam arti luas ingin melihat sesuatu terjadi, ingin melakukan sesuatu, ingin menggunakan simbol-simbol dan mencari jawaban atas pertanyaannya sendiri, menghubungkan penemuan yang satu dengan penemuan yang lain serta membandingkan sesuatu yang ditemukan oleh diri sendiri dengan yang ditemukan orang lain.

Model pembelajaran Guided Inquiry mem-berikan kesempatan kepada siswa sebagai sarana untuk mengembangkan sikap ilmiah yang sudah ada didalam diri masing-masing siswa. Sikap ilmiah yang dimiliki siswa tanpa sadar berkembang selama pembelajaran biologi melalui kegiatan praktikum dan diskusi. Esensi model pembelajaran inkuiri adalah mengajarkan pada siswa untuk memperoleh pengetahuan seperti halnya para peneliti biologi melakukan penelitian (Joyce, Weil \& Calhoun, 2000). Joyce, et al (2000) menambahkan bahwa model pembelajaran inkuiri bertujuan untuk membantu siswa mengembangkan kemampuan intelektual dan keterampilan yang dibutuhkan melalui pertanyaan dan jawaban yang diperoleh dari rasa keingintahuan yang dibangun melalui pengalaman belajar mandiri. Penerapan model pembelajaran Guided Inquiri tidak hanya berorientasi pada hasil belajar saja tetapi juga berorientasi pada proses belajar yang secara tidak sadar dapat mengembangkan keterampilan sikap ilmiah siswa. Hasil belajar dan sikap ilmiah siswa relevan dengan penelitian yang dilakukan oleh A'yun, Dewi \& Sudarmin (2015) tentang peningkatan hasil belajar kognitif dan sikap ilmiah siswa dengan model Think Pair Share berbasis Guided Inquiry.

Model pembelajaran Guided Inquiry meningkatkan kemampuan siswa dalam bekerja ilmiah melalui kegiatan penyelidikan yang dilakukannya sendiri. Pembelajaran inkuiri merupakan bentuk model pembelajaran yang berorientasi kepada siswa (student centered approach) (Majid, 2013). Pembelajaran inkuiri dirancang untuk mengajak siswa secara langsung ke dalam proses ilmiah ke dalam waktu yang relatif singkat (Trianto, 2007). Siswa tidak hanya membaca dan mendengarkan materi yang diberikan oleh guru tetapi siswa juga diberikan kesempatan untuk melakukan eksperimen secara langsung dengan objek yang nyata, kemudian berlatih berdiskusi berdasarkan hasil eksperimen yang telah dilakukan, menyusun data hasil eksperimen sesuai metode ilmiah, memecahkan masalah-masalah tertentu berkaitan dengan eksperimen, berlatih untuk memiliki sikap ilmiah dalam proses pem-belajaran biologi sebagai bagian dari sains, serta berpartisipasi langsung dalam proses pem-belajaran (Opara \& Oguzor, 2011).

Sikap ilmiah siswa berkembang selama tahapan sintaks model pembelajaran Guided Inquiry pada pembelajaran biologi. Pem-belajaran inkuiri mecakup beberapa tahapan meliputi (1) siswa disajikan suatu bidang penelitian (area investigation is posed to student), (2) siswa menyusun masalah (student structure the problem), (3) siswa mengidentifikasi masalah dalam penelitian (student identify the problem in the investigation), (4) siswa berspekulasi untuk memperjelas masalah (student speculate on ways to clear up the difficulty) (Joyce, et al, 2000). Pada fase 1 sintaks pembelajaran inkuiri, siswa disajikan bidang penelitian sehingga dapat merangsang rasa ingin tahu siswa. Pada fase 2 sintaks pembelajaran inkuiri, siswa menyusun masalah penelitian sehingga dapat mengembangkan ke-mampuan siswa dalam menyampaikan usulan. Pada fase 3 sintaks pembelajaran inkuiri, siswa mengidentifikasi masalah penelitian sehingga dapat mengembangkan kemampuan siswa dalam bekerjasama, berani mengajukan per-tanyaan dan berargumentasi, serta tekun dan tidak mudah menyerah. Pada fase 4 sintaks pembelajaran inkuiri, siswa menyusun solusi permasalahan dalam penelitian sehingga dapat mengembangkan kemampuan siswa dalam bekerjasama dan sikap jujur. Tiga fase belajar pengetahuan menurut teori Piaget terintegrasi pada tahapan sintaks pembelajaran inkuiri meliputi (1) fase eksplorasi, (2) fase pengenalan konsep, dan (3) fase aplikasi konsep.

Penerapan model pembelajaran Guided Inquiry memberikan dampak positif terhadap peningkatan sikap ilmiah siswa. Guru selalu berusaha memfasilitasi siswa dalam upaya mengembangkan sikap ilmiah siswa mulai dari awal hingga akhir kegiatan pembelajaran. Guru menyajikan gambar/ video untuk menarik minat siswa diawal kegiatan pembelajaran. Guru juga menyajikan alat dan bahan praktikum secara nyata untuk memotivasi siswa selama kegiatan penyelidikan. Siswa nampak antusias dan 
tidak bosan selama model pembelajaran Guided inquiry diterapkan. Pembelajaran inkuiri me-miliki beberapa dampak positif, yaitu (1) dapat melatih keterampilan bekerja ilmiah, (2) memberikan kebebasan berpikir serta menyadari kesementaraan sains, (3) memberikan gambaran kepada siswa tentang cara menyelidiki secara kreatif, (4) meningkatkan kreatifitas dan me-mungkinkan interaksi yang lebih baik antara guru dengan siswa (Faizi, 2013). Berdasarkan teori Gagne, terdapat 5 kategori segala sesuatu yang dipelajari manusia "The domains of learning" yaitu (1) keterampilan motoris, (2) informasi verbal, (3) kemampuan intelektual, (4) strategi kognitif, dan (5) sikap (Slameto, 2010). Guru tidak seharusnya memfokuskan siswa pada aspek kognitifnya saja, tetapi juga perlu mengembangkan aspek keterampilan dan aspek sikap. Siswa dengan kognitif yang baik harus diimbangi dengan sikap yang baik. Keseimbangan aspek kognitif dan aspek sikap relevan dengan penelitian Margiastuti, Parmin, \& Pamelasari (2015) tentang sikap ilmiah dan pemahaman konsep siswa melalui penerapan model Guided Inquiry.

\section{KESIMPULAN}

Berdasarkan hasil penelitian dapat disimpulkan bahwa penerapan model pem-belajaran Guided Inquiry dapat meningkatkan iklim kelas dan sikap ilmiah siswa di kelas XI IPA SMA. Peningkatan iklim kelas paling optimal terjadi pada aspek kekompakan siswa, sedangkan peningkatan sikap ilmiah siswa paling optimal terjadi pada aspek jujur.

Implikasi teoritis dapat dijadikan sebagai dasar referensi untuk mengembangkan Penelitian Tindakan Kelas lebih lanjut mengenai iklim kelas dan sikap ilmiah siswa. Implikasi praktis dapat digunakan untuk meningkatkan iklim kelas dan sikap ilmiah siswa selama proses pembelajaran di kelas, serta memberikan alternatif model pembelajaran yang tepat untuk meningkatkan kualitas pembelajaran.

\section{UCAPAN TERIMA KASIH}

Peneliti menyampaikan terimakasih kepada seluruh pihak yang mem-bantu terselesaikannya penelitian ini hingga tahap penyusunan laporan.

\section{DAFTAR PUSTAKA}

A'yun, Q., Dewi, N. R., \& Sudarmin. (2015). Efektivitas Model Think Pair Share (TPS) Berbasis Guided Inquiry pada Tema Sistem Transportasi untuk Meningkatkan Hasil Belajar Kognitif dan Sikap Ilmiah Siswa. Unnes Science Education Journal, 4 (3).

Alma, B. (2010). Guru Profesional (Menguasai Metode dan Terampil Mengajar). Bandung: Alfabeta.

Anwar, H. (2009). Penilaian Sikap Ilmiah dalam Pembelajaran Sains. Jurnal Pelangi Ilmu, Volume 2 No. 5.

Dimyati \& Mudjiono. (2010). Belajar dan Pembelajaran. Jakarta: Rineka Cipta.

Faizi, M. (2013). Ragam Metode Mengajarkan Eksakta pada Murid. Yogyakarta: Diva Press.

Fakhruddin, Eprina, E., Syahril. (2010). Sikap Ilmiah Siswa dalam Pembelajaran Fisika dengan Penggunaan
Media Komputer Melalui Model Kooperatif Tipe STAD pada Siswa Kelas X SMA Negeri 1 Bangkinang Barat. Jurnal Geliga Sains, 4(1): 18-22.

Gulo, W. (2002). Strategi Belajar-Mengajar. Jakarta: PT Gramedia Widiasarana Indonesia.

Hamruni. (2012). Strategi Pembelajaran. Yogyakarta: Insan Madani.

Joyce, B., Weil, M., \& Calhoun, E. (2009). Models of Teaching (Model-Model Pengajaran). Terj. A. Fawaid \& A. Mirya. Yogyakarta: Pustaka Belajar.

Karwati, E. \& Priansa, D. J. (2014). Manajemen Kelas (Classroom Management). Guru Profesional yang Inspiratif, Kreatif, Menyenangkan, dan Berprestasi. Bandung: Alfabeta.

Kusumah, W. \& Dwitagama, D. (2012). Mengenal Penelitian Tindakan Kelas. Jakarta: PT Indeks.

Majid, A. (2014). Strategi Pembelajaran. Bandung: PT Remaja Rosdakarya.

Margiastuti, S. N., Parmin, Pamelasari, S. D. (2015). Penerapan Model Guided Inquiry terhadap Sikap Ilmiah dan Pemahaman Konsep Siswa pada Tema Ekosistem. Unnes Science Educational Journal, 4 (3).

Olasehinde, K. J. \& Olatoye, R. A. (2014). Scientific Attitude, Attitude to Science and Science Achievement of Senior Secondary School Student in Katsina States, Nigeria. Journal of Educational and Social Research, Vol. 4 No. 1, MCSER Publishing, Rome Italy.

Opara, J. A., \& Oguzor, N. S. (2011). Inquiry Instructional Method and the School Science Curriculum. Current Research Journal of Social Science, 3(3), 188-189.

Otami, D. C., Ampiah, J. G., \& Anthony-Krueger, C. (2012). Factors Influencing Elective Science Students' Perception of Their Biology Classroom Environment in Low and High Academic Achieving Schools in the Central Region of Ghana. International Journal of Research Studios in Education, Volume 1 Number 1. 35-46.

Putra, S. R. (2013). Desain Belajar Mengajar Kreatif Berbasis Sains. Yogyakarta: DIVA Press.

Rubini, B. \& Liliasari. (2013). Basic Natural Science Contribution for Scientific Attitude Development and Values of Life. International Journal of Science and Research (IJSR), Volume 2 Issue 5.

Slameto. (2010). Belajar dan Faktor-Faktor yang Mempengaruhinya. Jakarta: Rineka Cipta.

Sugiyono. (2012). Metode Penelitian Pendidikan (Pendekatan Kuantitatif, Kualitatif dan R\&D). Bandung: Alfabeta.

Tsai, C. C., \& Tuan, H. L. (2006). Investigating the InquiryBased Instruction Effects the 8th Graders' Perceptions about Learning Environments in the Physical Science. APERA Conference 2006, 28-30 November 2006 Hongkong. Graduate Institute of Science Education, National Changhua University of Education, Taiwan.

Trianto. (2007). Model-Model Pembelajaran Inovatif Berorientasi Konstruktivistik. Jakarta: Prestasi Pustaka.

Widoyoko, S. E. P. (2012). Teknik Penyusunan Instrumen Penelitian. Yogyakarta: Pustaka Belajar. 